\title{
The Pharmacist-Patient Communication Model in the Chronic Disease Management Program
}

\author{
Annis Azhar Suryaningtyas ${ }^{1}$, Adi Nur Vianto ${ }^{2}$, Muh. Bintang Octaviano ${ }^{3}$, Setiyo Budi \\ Santoso $^{4}$ \\ $\left\{\right.$ sb@unimma.ac.id $\left.{ }^{4}\right\}$ \\ Department of Communication Science, Faculty of Psychology and Humanities, Universitas \\ Muhammadiyah Magelang ${ }^{1,2,3}$ \\ Department of Community and Clinical Pharmacy, Faculty of Health Science, Universitas \\ Muhammadiyah Magelang ${ }^{4}$
}

\begin{abstract}
This research was conducted at two Community Health Centers (hereafter Puskesmas); Muntilan and Tempuran. They are parts of the healthcare system in Magelang Regency, Indonesia. In analyzing the phenomenon, the researchers adopted the PatientCentered Communication proposed Debra Roter and Judith Hall. The Patient-Centered Communication describes a patient-centered communication model that includes four key elements: data collection, patient education and counseling, communication that builds partnership, and emotional response. The methodology of this research was the qualitative method using interactive data analysis techniques. Meanwhile, data triangulation was used as the data validity technique. The result showed that the pharmacist's communication model with Prolanis patients in Magelang Regency, especially at the two observed Puskesmas, had unconsciously applied the Patient-Centered Communication model. These were identified based on finding. The four elements of the Patient-Centered Communication model were all there. The two elements that stood out were education and counseling and partnership-building communication. Meanwhile, the elements of data collection and emotional responsiveness were found at the beginning and the end of the conversation.
\end{abstract}

Keywords: Patient-Centered Communication, Prolanis, Puskesmas

\section{Introduction}

Based on the Central Java Province Health Profile Data in 2019, there are 13.2\% of the total healthcare services in Magelang Regency are treating hypertension while $62.5 \%$ of them are treating Type 2 Diabetes Mellitus (henceforth T2DM). This means that the number of hypertension patients in Magelang Regency is at a moderate level and the number of T2DM patients tends to be high [1].

The Prolanis aims to invite chronic disease patients who visit the Level I Healthcare Facilities (Faskes Tk. I), in this case, the Puskesmas, to have an optimal quality of life. It is indicated with $75 \%$ of registered participants have "good" conditions especially for T2DM and hypertension examination. This is done as a step to prevent the complication of the disease [2].

Pronalis service focusing on T2DM and hypertension provides consultation service to monitor medication adherence. This illustrates that the paradigm of pharmaceutical services has 
now developed in the patient. According to Samadi in his research, he states that patient-focused pharmaceutical service requires effective communication between pharmacist and patient [3].

Besides, the importance of pharmacist's communication skill is also stated in the technical guideline for pharmaceutical service standard at Puskesmas which state that to achieve the optimal therapy of a patient, a pharmacist is required to have good communication skill. The communication skill is included in providing recommendations for patient treatment [4]. In counseling practice, the patient-centered communication model is very much needed by the pharmacist [5].

Based on the explanation above, it becomes important for a pharmacist to have communication skills to support pharmaceutical service so that it creates a consultation room to monitor and shape patient awareness in having medication adherence [6]. Consultation or counseling service carried out by a pharmacist has an impact on the level of understanding in Type 2 DM patients [7].

Meanwhile, according to Naughton, there have been many papers examining the patientcentered communication [8]. Some of them are patient communication with a doctor [9] and patient communication with the radiologist [10]. However, there are still relatively few that are specific to the pharmacists [8]. Therefore, it becomes interesting to study the communication model between pharmacy workers and patients in Prolanis in Magelang Regency to have new insights.

Researches discussing the communication between pharmacist and patient have been revealed by several researchers. For example, Olsson et al. in their research result stating that there is only little dialogue between pharmacists and patients discussing medication. Forty percent of the dialogue concerns non-medical matters and nearly half of the meetings are silent [11].

In line with that, there are several ways to analyze the communication between pharmacist and patient. For example, Nakayama et al. analyzed the phenomenon of communication between pharmacist and patient using the Roter Interaction Analysis Sistem (RIAS) [12]. Greenhill et al., on the other hand, used the Calgary-Cambridge Guide. From the result of his research, Greenhill suggested a practical implication that a pharmacist needs to be trained in communication skill including communication used for patient-centered consultation [13].

Naughton in his paper also suggests to use the Calgary-Cambridge Guide to analyze the phenomenon of communication between pharmacist and patient. He also recommends another model called the Expanded Four Habits Model. This model draws on the explicit examples of how to build relationship with the patient, identify the patient problem, explore the patient's medical history, and express empathy to patient. Another model found is PaCT model. PaCT stands for the Patient-Centered Communication Tools (PaCT). It includes 23 clinical communication skills categorized into five "tools". The tools are establishing a connection, exploring and integrating the patient's perspectives, demonstrating interest and empathy, collaborating and educating, and communicating with finesse) [8].

The phenomenon of communication between the pharmacist and patient in Prolanis Magelang Regency written in this research is analyzed using the theory of Patient-Centered Communication proposed by Debra Roter and Judith Hall. The Patient-Centered Communication is chosen because this model has also been used to analyze the phenomenon of communication between the public health workers and diabetes patients [14].

Patient-Centered Communication describes a patient-centered communication model that includes four key elements namely data collection, patient education and counseling, communication that builds partnerships, and emotional response. These four elements are supported by high context communication which refers to implicit and nonverbal messages [15]. 
The data collection discussed in the theory is the ability of the healthcare professional to help patient to find out their health codes. Patient education and counseling includes the skill of healthcare professional to help the patient to understand his condition and help him in making decision. Partnership-building communication means helping patients to become more concern of their medical decision and action. The emotional responsiveness refers to the extent to which healthcare professional understands and reflects the patient's emotional expression [15]. This model was chosen to identify the initiation of each communication skill which appears in the conversation between pharmacist and patient in the Prolanis at Puskesmas in Magelang.

\section{Method}

This is a descriptive qualitative research. It is because the data are description of the pharmacist's communication with patients. The informants were selected using purposive technique by determining two criteria--pharmacists who are in charge of Prolanis and patients of Prolanis. Data in this study was obtained using interview technique involving Prolanis pharmacists two Puskemas, Muntilan dan Tempuran in Magelang, and Prolanis patients. Besides that, the researchers also conducted observation by observing the conversation between pharmacists and patients of Prolanis participants. The data, later on, be validated using triangulation by comparing and combining the results of interview with pharmacists and conversation observation between pharmacists and patients. They were then presented using matrices and were categorized based on the four elements of Patient-Centered Communication. After that, the researchers restore the sorted data to be adjusted based on the problem formulation and problem limitation. The final data was presented narratively and the conclusion was drawn based on the essence of the interview and observation. They were all set to answer the problem formulation which is then synchronized with the real situation that occurred in the field.

\section{Results and Discussion}

\subsection{Research Finding}

In the Prolanis program at Puskemas Muntilan and Tempuran, there were 48 communications between pharmacist and patient. Based on the observation, the conversations spoken between the pharmacist and patients are in accordance with the patient-centered communication model proposed by Debra Roter and Judith Hall. All four elements in the Patient-Centered Communication model were shown up implicitly in the conversation between the Prolanis pharmacist and patients. This was because the meeting between Prolanis pharmacist and patients was quite intense and had been a routine. The explanation them is as follows:

a. First element, communication is functioned to gather the data. The process of gathering the data, the communication between pharmacist and patient was only about confirming patient's identity by asking their names. It was seen from the interaction between the pharmacist and informant 19 and 1 . 
Table 1. Communication is functioned to gather the data

\begin{tabular}{|c|c|}
\hline Informant Code & Conversation \\
\hline $\begin{array}{l}\text { Puskesmas Muntilan: 19, 23, 24, 22, 21, 8, } \\
9,14,11,20,7,13,18,4,3,16,5,15,17 \text {, } \\
10,1 \text {, and } 6\end{array}$ & $\begin{array}{l}\text { Message: Digging up identity by calling the patient's } \\
\text { name--a pharmacist's conversation with an informant } \\
\text { code 19. "Pharmacy 1: Mr. Suhadi, Mr. Suhadi?" }\end{array}$ \\
\hline $\begin{array}{l}\text { Puskesmas Tempuran: } 1,2,4,5,6,7,10,11 \text {, } \\
13,14,15,16,17,18,19,20,21,22,23,25 \text {, } \\
29,30,34,37,38 \text {, and } 39\end{array}$ & $\begin{array}{l}\text { Message: Exploring identity by calling the patient's } \\
\text { name and address For example, a pharmacist's } \\
\text { conversation with a code } 1 \text { informant. "Pharmacy } 1: \mathrm{Bu} \\
\text { Saripah, Kebon Agung yes?" }\end{array}$ \\
\hline
\end{tabular}

Source: Communication Observation Data

According to Informant I, a Prolanis pharmacist, the data collection occurring in the communication between a pharmacist and a patient is not very in-depth because the patient had had communication with the doctor before. The communication of a pharmacist and a patient happens afterward that. This can be seen in the interview with Informant I as follows:

"It's usually from the doctor. The doctor asks the patient about what they feel and prescribe the medication. After that, the patients bring the prescription to us. We'll give him medicines based on the prescription written by the doctor." (Source: interview with Informant I)

It was explained by the patient of Prolanis at Puskesmas Tempuran with informant code 21, that he told the doctor about what they felt.

"The medicine given is always the same. If there is a side effect like cough or dizziness, I will tell the doctor." (Source: interview with Informant 21 in Javanese language).

b. Second element, communication is used to make a personal connection between the pharmacist and the patient. The personal connection among them is formed naturally. It is because Prolanis program has regularly scheduled and is quite intense.

Table 2. Communication is used to make personal connection among them

\begin{tabular}{|c|c|}
\hline Informant Code & Conversation \\
\hline $\begin{array}{l}\text { Puskesmas Muntilan: } 19,23,24,22,21,8, \\
9,14,11,20,7,13,18,4,3,16,5,15,17, \\
10,1 \text {, and } 6\end{array}$ & $\begin{array}{l}\text { Asking signature of a referral letter from Informant } \\
\text { Code } 23 \text {. } \\
\text { "Pharmacy 1: Pak Tri Ilham! Mr. Tri Ilham? Please, sign } \\
\text { here. Where is it, here? Pharmacy } 1 \text { :Yes. Please sign } \\
\text { here, too" }\end{array}$ \\
\hline $\begin{array}{l}\text { Puskesmas Tempuran: } 1,2,4,5,6,7,10 \text {, } \\
11,13,14,15,16,17,18,19,20,21,22 \text {, } \\
23,25,29,30,34,37,38 \text {, and } 39\end{array}$ & $\begin{array}{l}\text { Asking signature of a referral letter from Informant } \\
\text { Code } 23 \text {. } \\
\text { "Pharmacy 1: Pak Tri Ilham! Mr. Tri Ilham? Please, sign } \\
\text { here. Where is it, here? Pharmacy } 1 \text { :Yes. Please sign } \\
\text { here, too" }\end{array}$ \\
\hline
\end{tabular}

From the interview, Informant I state that the partnership-building communication element can arise from good, personal relationship between the pharmacist and patient.

"It is usually you create your own. Either we start first or the patient starts first. Yes. We are more familiar because we must know the patient's condition as well. Sometimes, we are very good at joking, some are not hehe (chuckling)." (Source: interview with Informant I) 
It was also stated by Informant code 21 that the pharmacist is friendly to patient. They are also able to guide the patient to be active for his medical action even it is only about the administration.

"The pharmacist is very carefully taking care of elderly patients. They give us directions like "please sign here". I am old, sometimes I do not understand and forget what i must do." (Source: interview with Informant code 21 in Javanese language).

c. Third element, communication has an educational value for the patient. This educational value covers how to take the medicine, its composition or substance, and the side effect. This conversation happens but not so often. It is because the patient has already known that information in the beginning of their treatment. The communication can reoccur if there is a change of medicines or how to take them.

Table 3. Communication includes educational value and counseling

\begin{tabular}{|c|c|}
\hline Informant Code & Conversation \\
\hline $\begin{array}{l}\text { Puskesmas Muntilan: 19, 23, } \\
\text { 24, 21, and } 17\end{array}$ & $\begin{array}{l}\text { Communication is about the medication, the type of the medicines, } \\
\text { how to take them, etc. This is as what is stated by Informant code } \\
\text { 23. } \\
\text { "Pharmacy 1: There are two kinds of medicines, sir. Patient: Alright. } \\
\text { Pharmacy 1: Take them after a meal." }\end{array}$ \\
\hline $\begin{array}{l}\text { Puskesmas Tempuran: } 1,6,7 \text {, } \\
10,13,17,19,18 \text {, and } 23\end{array}$ & $\begin{array}{l}\text { Communication is about the medication, the type of the medicines, } \\
\text { how to take them, etc. This is as what is stated by Informant code } \\
\text { 13. } \\
\text { "Pharmacy 1: Please take this medicine first, Ma'am. Patient: Alright. } \\
\text { Pharmacy 1: Please directly take two pills. Patient: Very well. } \\
\text { Yes.Pharmacy 1: Take them before a meal" }\end{array}$ \\
\hline
\end{tabular}

A pharmacist knows the fact that not all medicines are same. There are some different aspects of different medicines. That is why a pharmacist thinks he needs to give information of the prescribed medicines. In this situation, the element of education and counseling arises.

"There are some patients who still do not understand also about the medication, so we inform them how to take them and when to take them to avoid misleading because there is a patient taking his medicine by negectling the right time to take them" (Source: interview with Informant I)

Informant I think that it is important for the patients to improve their medication adherence and to take the madicine regularly.

"The important thing is that we always remind patients. We always inform how to take the medicines so that they can take them safely and regularly." (Source: interview with Informant I)

The information obtained from Informant I is also supported by informant with code 21 . He states that the pharmacist gives directions about how to take the medicines as follows:

"Yes. That's true (telling us, the researchers, about the procedure of taking the medicines) for example this (showing the medicine) should be taken at night, this one (showing us another medicine) is at noon, and it is sublingual." (Source: interview with Informant code 21 in Javanese). 
He also states that the pharmacists are friendly to patients. They are able to direct the patient to be active in his medical actions even it is only the administration.

"Pharmacists should be careful in taking care of elderly patients. They must give directions such as "Please sign here". I am old, so sometimes I do not understand or forget what to do." (Source: interview with Informant code 21 in Javanese language).

d. The last element, communication is used as a means of expressing emotion. Nonverbal communication like smiling, diction, intonation, showing sympathy to the patients.

Table 4. Communication Is To Express Emotional Response

\begin{tabular}{|c|c|}
\hline Informant Code & Conversation \\
\hline $\begin{array}{l}\text { Puskesmas Muntilan: } 8,9,14,11 \text {, } \\
20,13,3,16,5,17,10,1 \text {, and } 6\end{array}$ & $\begin{array}{l}\text { Communicate and respect by expressing gratitude, saying } \\
\text { good bye and facial expression like smiling. It is just like } \\
\text { what is said by the informant code } 8 \text {. } \\
\text { Patient: Thanks you. Pharmacy 1: You are welcome. Patient: } \\
\text { Hehehe (chuckling). }\end{array}$ \\
\hline $\begin{array}{l}\text { Puskesmas Tempuran: 1, 2, 10, 11, } \\
19,21,22,25,29 \text {, and } 30\end{array}$ & $\begin{array}{l}\text { Communicate and respect by expressing gratitude saying } \\
\text { good bye and facial expression like smiling. It is just like } \\
\text { what is said by the informant code. } \\
\text { "Patient: Yes, thank you. Pharmacy 1: Alright." }\end{array}$ \\
\hline
\end{tabular}

Source: Communication Observation Data

In the fourth element, the emotional responsiveness from pharmacist to patient is built implicitly when the pharmacist notices the changes that occur in the patient's drug treatment.

"Yes (we communicate with the patient responsibly). Especially about dosage change. When the patient's condition is good, the dosage decrease and when the patient's condition worse the dosage increases. (Source: interview with Informant I).

Seen from data, the communication between pharmacist and patient in Prolanis program is at the interpersonal communication level. The message delivered by the pharmacist is easily understood by the patients. It is because the pharmacists use simple language. Thus, conversations can be developed in a flexible, friendly, and familial way.

\subsection{Discussion}

Communication between the pharmacist and patients in Prolanis program at two Puskesmas, Muntilan and Tempuran in Magelang Regency, is unconsciously oriented towards the patient-centered communication. The patient-centered communication model emphasizes implicit messages which can hopefully form a personal relationship between the pharmacist and the patient. Our findings in patients with chronic disease suggest that they require motivational intervention to manage their socio-emotional problems, quality of life and perception of the disease to the problem of drug therapy interactions [16]-[19].

Meanwhile, there is an element of the patient-centered communication model in this research that appear but is not deep. It is the data gathering element. The data gathering shows up only little because the communication between pharmacists and patients in Prolanis program is not the primary interaction. On the other hand, there are three elements of patient-centered communication that stand out verbally and implicitly. They are communication for patient 
education and counseling, communication with emotional responsiveness, and communication that builds partnership. In gathering the patient's data, even though the patient has informed the doctor about what his feel, it is better if the pharmacist also knows it. The hope is that the pharmacist will also have data about the patient's real condition so that it creates consultation room that enhances the understanding and medication adherence of the patient.

Pharmacist communication with Prolanis members at two Puskesmas in Magelang Regency, however, has fulfilled the elements of patient-centered communication. According to Naughton, those elements include openness and clarity in telling what they feel and being a good listener [8]. Openness refers to how the patient feels the pharmacist friendly service. A pharmacist also plays a role as a good listener when he finds a patient who is confused about what medicine he should take instead of the drug that is not available in stock. In addition, the patient also feels helped by the pharmacist for their explanation of how to take the medicine, its side effect, and so on. It can be interpreted that the pharmacist has practiced the concept of clarity in revealing the health problems.

Based on the discussion, the researchers can reveal that the communication model of the pharmacist and patients of Prolanis program at two Puskesmas in Magelang Recency as follows: (1) the communicator is the pharmacist whereas the communicants are the patients, (2) the communication between them emphasizing the education and counseling and implicit message of building partnership with full of sympathy and empathy. It creates a good connection between them. Another supportive aspect is that they communicate quite intense. This is in line with Little John et al. who state that patient-centered communication is functioned to build a connection among the healthcare professional and his patients:

"Our relationship influences our health behaviours by showing what is expected and also by encouraging positive and negative behaviours. This section explores four theories of how social relationships are related to health: (1) theory of normative social influence; (2) social support theory; (3) patient-centered communication; and (4) structurational divergence theory" [15]

However, the patient-centered communication model between the pharmacist and the Prolanis patients do not emphasize the message exchange about sharing problem and solution between them as in Utrecht's Model for Patient centred Communication in the Pharmacy [20] and A Person's-Centered Communication and Person's-Centered Communication Reflection Model [21]. After finding and discussing the fact that there are some communication model between the healthcare professional and theirs patients, the pharmacists really need communication skill. This makes communication skill often be offered in pharmaceutical curriculum, patient-centered communication is one of the offered models [22][23]. The patientcentered communication model, if it is well applied, can increase patients' satisfaction and belief to the healthcare professionals [24].

\section{Conclusion}

The patient-centered communication model applied to the Prolanis program at Muntilan and Tempuran Puskesmas is suitable for building personal relationships between pharmacists and patients. This model emphasizes the process of exchanging messages with educational and counseling values, building personal relationships, expressing sympathy (emotions), and implicit data gathering. Communication skills training for prospective pharmacists needs to be 
provided. Pharmacists also need to know the various kinds of communication models that can be applied in the context of pharmacist-patient communication.

\section{Acknowledgement}

Researchers would like to say thank you to the Research Institute for Development and Community Service (LP3M) University of Muhammadiyah Magelang for its support so that we can complete this paper well.

\section{References}

[1] Profil Kesehatan Provinsi Jawa Tengah, 'Profil Kesehatan Prov. Jateng Tahun 2019', Profil Kesehat. Jateng, vol. 3511351, no. 24, pp. 273-275, 2019.

[2] BPJS, 'Panduan praktis Prolanis (Program pengelolaan penyakit kronis)', BPJS Kesehat., 2014.

[3] Sarmadi, 'IDENTIFIKASI KOMUNIKASI EFEKTIF ANTARA TENAGA TEKNIS WILAYAH KECAMATAN KEMUNING', vol. 12, no. 1, pp. 1-7, 2017.

[4] K. K. RI, Petunjuk Teknis Standar Pelayanan Kefarmasian Di Puskesmas. Jakarta: Kementerian Kesehatan RI. Direktorat Jenderal Kefarmasian dan Alat Kesehatan, 2019.

[5] I. K. A. Mulyono, S. Irawati, A. P. Susilo, and M. Claramita, 'Pharmacist-patient communication in Indonesia: The roter interaction analysis system (RIAS) in a socio-hierarchical context', Pharm. Educ., vol. 19, no. 1, pp. 359-369, 2019.

[6] M. L. Ilardo and A. Speciale, 'The community pharmacist: Perceived barriers and patient-centered care communication', Int. J. Environ. Res. Public. Health, vol. 17, no. 2, 2020, doi: 10.3390/ijerph17020536.

[7] M. Elly, 'Pengaruh Pemberian Konseling oleh Apoteker Terhadap Tingkat Pengetahuan Pasien Diabetes Mellitus Tipe 2 di Apotek Kimia Farma 75 Kota Kediri', no. 1.

[8] C. Naughton, 'Patient-Centered Communication', Pharmacy, vol. 6, no. 1, p. 18, 2018, doi: 10.3390/pharmacy6010018.

[9] R. Effendi, V. Sukmayadi, and I. R. Pandjaitan, 'The effects of doctors' interpersonal communication on low-income inpatients' satisfaction level', J. Komun. Malays. J. Commun., vol. 35, no. 1, pp. 57-70, 2019, doi: 10.17576/JKMJC-2019-3501-05.

[10] A. Vijayasarathi, R. Kharkar, and N. Salamon, 'Strategies for Patient-Centered Communication in the Digital Age', Curr. Probl. Diagn. Radiol., vol. 48, no. 3, pp. 210-215, 2019, doi: 10.1067/j.cpradiol.2018.05.004

[11] E. Olsson, P. Ingman, B. Ahmed, and S. Kälvemark Sporrong, 'Pharmacist-patient communication in Swedish community pharmacies', Res. Soc. Adm. Pharm., vol. 10, no. 1, pp. 149-155, 2014, doi: 10.1016/j.sapharm.2013.03.001.

[12] C. Nakayama, S. Kimata, T. Oshima, A. Kato, and A. Nitta, 'Analysis of pharmacist-patient communication using the Roter Method of Interaction Process Analysis System', Res. Soc. Adm. Pharm., vol. 12, no. 2, pp. 319-326, 2016, doi: 10.1016/j.sapharm.2015.05.007.

[13] N. Greenhill, C. Anderson, A. Avery, and A. Pilnick, 'Analysis of pharmacist-patient communication using the Calgary-Cambridge guide', Patient Educ. Couns., vol. 83, no. 3, pp. 423431, 2011, doi: 10.1016/j.pec.2011.04.036.

[14] D. Paiva, L. Abreu, A. Azevedo, and S. Silva, 'Patient-centered communication in type 2 diabetes: The facilitating and constraining factors in clinical encounters', Health Serv. Res., vol. 54, no. 3, pp. 623-635, 2019, doi: 10.1111/1475-6773.13126.

[15] S. W. Littlejohn, K. A. Foss, and J. G. Oetzel, Theories of Humas Communication, vol. 53, no. 9. Waveland Press, Inc., 2017. 
[16] S. B. Santoso, H. Lutfiyati, R. I. Prasidha, S. Ratnafuri, and K. A. Azzahra, 'What do patients with HIV-infection perceive and know regarding to antiretrovirals? An exploration among participants undergoing controlled-therapy', Technol. Rep. Kansai Univ., vol. 62, no. 04, p. 7, 2020.

[17] S. B. Santoso, D. A. Perwitasari, I. N. Faridah, and A. A. Kaptein, 'Hubungan kualitas hidup dan persepsi pasien tentang penyakit diabetes mellitus tipe 2 dengan komplikasi', Pharmaciana, vol. 7, no. 1, p. 33, May 2017, doi: 10.12928/pharmaciana.v7i1.4699.

[18] D. A. Perwitasari, S. B. Santosa, I. N. Faridah, and A. A. Kaptein, 'Illness Perceptions and Quality of Life in Patients with Diabetes Mellitus Type 2', Indones. J. Clin. Pharm., vol. 6, no. 3, pp. 190199, 2017, doi: 10.15416/ijcp.2017.6.3.190.

[19] S. B. Santoso and M. Azalea, 'Potensi Interaksi Antibiotik dengan Obat Penyerta pada Peresepan Pasien ISPA Dan PPOK', CERATA J. Ilmu Farm., vol. 9, no. 1, p. 8, 2018.

[20] M. Wolters, R. van Hulten, L. Blom, and M. L. Bouvy, 'Exploring the concept of patient centred communication for the pharmacy practice', Int. J. Clin. Pharm., vol. 39, no. 6, pp. 1145-1156, 2017, doi: 10.1007/s11096-017-0508-5.

[21] V.Zoffmann, I. Harder, and M. Kirkevold, 'A person-centered communication and reflection model: Sharing decision-making in chronic care', Qual. Health Res., vol. 18, no. 5, pp. 670-685, 2008, doi: 10.1177/1049732307311008.

[22] M. Wolters, J. G. van Paassen, L. Minjon, M. Hempenius, M.-R. Blokzijl, and L. Blom, 'Design of a Pharmacy Curriculum on Patient Centered Communication Skills', Pharmacy, vol. 9, no. 1, p. 22, 2021, doi: 10.3390/pharmacy9010022.

[23] A. Kerr et al., 'How can pharmacists develop patient-pharmacist communication skills? A realist review protocol', Syst. Rev., vol. 6, no. 1, pp. 1-7, 2017, doi: 10.1186/s13643-016-0396-0.

[24] J. W.-F. Elena A. Platonova, Haiyan Qu and Article, 'Patient-centered communication: dissecting provider communication Abstract', Int. J. Health Care Qual. Assur., vol. 7, no. 4, pp. 1-40, 2018, doi: 10.1108/09526862199400001. 